\title{
Social Skill: Pustakawan dan Minat Baca
}

\author{
Ernawati \\ Mahasiswa Pascasarjana UIN Sunan Kalijaga Yogyakarta \\ Jurusan Ilmu Perpustakaan dan Informasi 2018
}

\begin{abstract}
Abstrak
Dalam dunia perpustakaan, seorang pustakawan adalah komponen yang paling vital, dimana keberhasilan perpustakaan dalam memberikan layanan informasi sangat ditentukan oleh kualitas, profesionalitas dalam sistem layanan yang berkarakter. Kualitas tenaga pustakawan untuk perpustakaan umum berbeda dengan kulaitas tenaga pustakawan perpustakaan perguruan tinggi. Pustakawan adalah kunci utama majunya perpustakaan. Setiap pustakawan dalam berinteraksi dengan orang lain, baik itu sesama pustakawan maupun pengguna (user) terlebih umumnya pada masyarakat pembelajar membutuhkan soft skill. Kesuksesan yang dimiliki oleh pustakawan bukan hanya sekedar keterampilan teknis, melainkan kualitas diri pustakawan yang dilengkapi dengan sifat, sikap dan nilai-nilai kepribadian pustakawan itu sendiri.

Penelitian inifokus terhadap soscial skill sebagai pustakawan sekolah dalam mengembangkan minat baca di perpustakaan sekolah. Keseimbangan antara soft skill dan Comunnicator style yang dimiliki oleh pustakawan ini yang kemudian mampu memberikan energi positif bagi citra perpustakaan dan keprofesionalisme seorang pustakawan itu sendiri. Dengan cara-cara komunikasi yang efektif menjadikan pustakawan sebagai sahabat bagi penggunanya.
\end{abstract}

Kata Kunci: Social Skill, Pustakawan Sekolah, Minat Baca 


\section{Latar Belakang}

Undang-Undang Sistem Pendidikan Nasional (UU No.2 Tahun 1989), menjelaskan bahwa sarana penunjang kegiatan belajar mengajar dinamakan "Sumber Daya Pendidikan". ${ }^{1}$ Pendidikan tidak akan mungkin terselenggara dengan baik apabila para tenaga kependidikan maupun para peserta didik tidak didukung oleh sumber belajar yang diperlukan untuk menyelenggarakan kegiatan belajar mengajar yang bersangkutan.

Sesuai dengan UU Sisdiknas tahun 2003, pustakawan perpustakaan sekolah masuk dalam kategori tenaga kependidikan. Tenaga kependidikan meliputi: pengelola satuan pendidikan, penilik, pamong belajar, pengawas, peneliti, pengembang, pustakawan, laboran dan teknisi sumber belajar. ${ }^{2}$ Mengacu pada pasal 35 PP No. 19 Tahun 2005 tentang Standart Nasional Pendidikan menunjukan bahwa tenaga perpustakaan dianggap sebagai pendukung kegiatan pembelajaran. Secara positif menjelaskan bahwa tenaga perpustakaan sebagai posisi yang integral dari proses pembelajaran. ${ }^{3}$

Dalam dunia perpustakaan, seorang pustakawan adalah komponen yang paling vital, dimana keberhasilan perpustakaan dalam memberikan layanan informasi sangat ditentukan oleh kualitas, profesionalitas dalam sistem layanan yang berkarakter. ${ }^{4}$ Agar dapat memberikan layanan yang baik sesuai dengan fungsinya, perpustakaan memerlukan tenaga yang memadai sesuai dengan jumlah dan kualitas yang harus dimilikinya. Jumlah dan kualitas dari tenaga pustakawan yang bekerja berbeda berdasarkan jenis perpustakaan yang dinaunginya.

Kualitas tenaga pustakawan untuk perpustakaan umum berbeda dengan kulaitas tenaga pustakawan perpustakaan perguruan tinggi. Begitu juga dengan kualitas tenaga pustakawan yang bekerja di perpustakaan

${ }^{1}$ Undang-undang R.I. No.2 Tahun 1989 tentang Sistem Pendidikan Nasional. Jakarta: Armas Duta Jaya, 189.

${ }^{2}$ Darmono. Manajemen dan Tata Kerja Perpustakaan Sekolah. (Jakarta: Grasindo 2001).

${ }^{3}$ Darmono, Perpustakaan Sekolah Pendekatan Aspek Manajemen dan Tata Kerja, (Jakarta: Grasindo 2007). 259

${ }^{4}$ Maslahah, Khoirul. Bunga Rampai Layanan Perpustakaan berbasis Humanisme.(Surakarta: Bunga Rampai), 2013. 
sekolah. Walaupun dari jenjang pendidikan dan ilmu yang sama. Akan tetapi berbeda hasil kualitas penyelenggaran perpustakaan sangat tergantung pada kapasitas sumber daya tenaga pengelolanya.

Pustakawan ataupun tenaga perpustakaan bukan lagi orang yang hanya melakukan kegiatan rutin seperti katalog, klasifikasi, inventarisasi dan sebagainya. Melainkan menjadi patner guru bahkan fasilitator dalam proses pembelajaran siswa disekolah. Dalam hal ini pustakawan juga harus memilki kemampuan untuk mengembangkan koleksi yang seimbang sesuai kebutuhan perpustakaannya serta mampu memberikan materi pembelajaran yang terkait tentang literasi informasi kepada siswa.

Pustakawan sekolah adalah tenaga kependidikan berkualifikasi serta profesional yang bertanggung jawab atas perencanaan dan pengelolaan perpustakaan sekolah, didukung oleh tenaga yang mencukupi, bekerja sama dengan semua anggota komunitas sekolah, dengan berhubungan dengan perpustakaan umum, dan lain-lainnya. ${ }^{5}$ Terkait hal diatas, bahwa peran pustakawan ialah memberikan sumbangan pada misi dan tujuan sekolah, termasuk prosedur evaluasi dan mengembangkan serta melaksanakan misi dan tujuan perpustakaan sekolah. ${ }^{6}$

Pustakawan sekolah hendaknya memiliki pendidikan profesional dan berkualifikasi, dengan melakukan pelatihan tambahan dibidang teori pendidikan dan metodologi pembelajaran. Karena kompetensi yang dimiliki oleh seorang pustakawan sangat mempengaruhi kualitas layanan yang diberikan kepada peserta didik selaku pengguna atau pemustaka. Semua orang yang bekerja di perpustakaan sekolah harus memiliki sifat yang luwes dan mudah bergaul dengan semua kalangan. Serta tidak membedakan fasilitas layanan yang diberikan kepada seluruh pemustaka yang membutuhkan.

Profesi pustakawan pada masa dahulu sering diartikan dalam kalangan masyarakat sebagai sosok yang menakutkan dan membosankan. Namun saat ini pustakawan mengikuti proses yang terjadi akibat dampak

\footnotetext{
${ }^{5}$ Suherman, Perpustakaan Sebagai Jantung Sekolah Referensi Pengelolaan Perpustakaan Sekolah (Bandung: MQS Publishing, 2009), 30.

${ }^{6}$ Ibid. 31
} 
perubahan zaman yaitu pustakawan lebih berperan sebagai penyedia dan pemberi informasi serta bisa juga dikatakan bahwa pustakawan menjadi pembawa informasi. ${ }^{7}$

Begitu juga sama halnya dengan perpustakaan seperti organisme yang selalu tumbuh dan berkembang dari masa ke masa. Dimana perkembangan tersebut merupakan cerminan dari sebuah peradaban. Perpustakaan selalu beradaptasi dengan kemajuan zaman serta berupaya memahami perkembangan kebutuhan penggunanya. Sehingga perpustakaan kedepannya menjadi sumber rujukan bagi pengguna dalam menelusur informasi. Mau tidak mau perpustakan harus bisa mengimbangi kemajuan teknologi dikarenakan perkembangan zaman secara terus menerus. Jika perpustakaan tidak mengikuti perkembangan zaman, maka tinggal menunggu saatnya saja perpustakaan akan ditinggalkan penggunanya.

Dalam menyikapi segala perkembangan yang terjadi disaat ini sebaiknya perpustakaan lebih responsif dalam mengaktualisasikan diri guna mewujudkan segala bentuk layanan dan ketersedian informasi dalam segala bentuk layanan terbaik untuk pengguna. ${ }^{8}$ Pemanfaatan kemajuan teknologi akibat perubahan zaman sangat dipengaruhi oleh kemampuan sumber daya manusia dalam memahami dan mengoperasikan teknologi dalam penyebarluasan informasi.

Perpustakaan sebagai sumber informasi, baik tercetak maupun non cetak. Terlepas dari jenisnya tetap saja merupakan lembaga institusi yang dimainstreankan sebagai pusat sumber daya informasi yang mengelola informasi dan menyajikannya, agar pemustaka mampu menghasilkan informasi-informasi baru dari informasi yang diperolehnya diperpustakaan. ${ }^{9}$ Perpustakaan merupakan salah satu pusat layanan masyarakat yang menangani mengenai informasi. Sedangkan pustakawan sebagai pengelola perpustakaan merupakan bagian dari masyarakat.

\footnotetext{
${ }^{7}$ Fatmawati, Endang. The Art Library: Ikatan Esai Bergizi tentang Seni Mengelola Perpustakaan. (Semarang: Badan Penerbit Diponegoro, 2010), 164.

${ }^{8}$ Hartono. Manajemen Perpustakaan Sekolah: Menuju Perpustakaan Modern dan Profesional. (Yogyakarta: Ar-Ruz Media, 2016). 236

${ }^{9}$ Suwarno,Wiji. Library Life Style.(Yogyakarta: Ladang Kata, 2016). 2
} 
Pelayanan kepada masyarakat adalah misi utama perpustakaan. Untuk mewujudkan pelayanan prima maka pustakawan harus meningkatkan mutu pelayanannya. Sebagai pelayan masyarakat (public service) sudah tentu banyak sekali kejadian maupun pengalaman saat berinteraksi dengan pengguna, apakah menyenangkan atau bahkan menjengkelkan. Padahal pustakawan juga dituntut untuk mampu mengenali perasaan emosionalnya sendiri dan juga orang lain (user).

Sangat penting hal ini untuk diketahui mengingat pustakawan harus mampu (survive) dalam mengatasi tantangan dan tekanan baik dari dalam maupun luar perpustakaan. Dengan memiliki kesadaran itulah, menadi awal mulanya bagi pustakawan sebagai pemiliki kecerdasan emosi (emotional quotient. Oleh karenanya pustakawan harus mengembangkan dirinya dan mempunyai berbagai macam keahlian (multi-skill).

Untuk menghadapi kecanggihan teknologi tersebut, pustakawan harus memiliki kemampuan melihat dunia dari berbagai sudut pandang berbeda. pustakawan harus sudah memiliki kemampuan Soft skill guna menciptakan dan mampu mengimbangi masyarakat pembelajar tersebut. ${ }^{10}$

Arti penting penguasaan soft skill bagi pustakawan adalah untuk meningkatkan institusi, kepekaan dan kepedulian kita dalam dunia kerja. Apabila soft skill ini dimiliki oleh setiap pustakawan maka sebutan sebagai pustakawan profesional menjadi kebanggaan setiap orang yang menyebut dirinya sebagai pustakawan.

Pustakawan adalah kunci utama majunya perpustakaan. Setiap pustakawan dalam berinteraksi dengan orang lain, baik itu sesama pustakawan maupun pengguna (user) terlebih umumnya pada masyarakat pembelajar membutuhkan soft skill. Kesuksesan yang dimiliki oleh pustakawan bukan hanya sekedar keterampilan teknis, melainkan kualitas diri pustakawan yang dilengkapi dengan sifat, sikap dan nilai-nilai kepribadian pustakawan itu sendiri.

\footnotetext{
${ }^{10}$ Fatmawati, Endang. The Art Library: Ikatana Esai Bergizi tentang Seni Mengelola Perpustakaan.166
} 
Dengan kepribadian yang baik, diharapkan pustakawan mampu memberikan kualitas pelayanan yang semakin baik. Kepribadian yang baik ini disebut sebagai kepribadian positif yang tercermin dari tiga aspek yaitu: tingkah laku yang baik, (good behaviour), penampilan yang baik (Good appearance), dan pembawaan yang baik (good performance). ${ }^{11}$ Dengan begitu citra perpustakaan memberikan aura positif karena dipengaruhi oleh lingkungan dan kualitas dari layanan pustakawan itu sendiri.

Banyak aspek yang menentukan kualitas layanan perpustakaan ideal. Salah satu aspek yang dapat mempengaruhi hal tersebut yaitu komunikasi efektif pustakawan pada saat memberikan pelayanan kepada pengguna. Komunikasi merupakan kebutuhan dasar manusia sebagai mahkluk sosial dan merupakan bagian terpenting dalam dunia kehidupan terutama dunia kerja yang berinteraksi dengan masyarakat.

Seorang pustakawan pada saat berkomunikasi dengan pengguna memiliki posisi sebagai komunikator sedangkan pengguna merupakan komunikan. Komunikasi yang efektif akan terjadi bila pustakawan mampu menyelaraskan gaya berkomunikasinya dengan gaya komunikasi penggunanya. Komunikasi antara pustakawan dengan penggunya bukan hanya sekedar pembicaraan sebatas permintaan dan bantuan, namun lebih pada karater dan bagaimana seorang pustakawan dan gaya komunikasi (communicator style) yang digunakan pustakawan dalam memberika pelayanan informasi kepada pengguna.

Keseimbangan antara soft skill dan Comunnicator style yang dimiliki oleh pustakawan ini yang kemudian mampu memberikan energi positif bagi citra perpustakaan dan keprofesionalisme seorang pustakawan itu sendiri. Dengan cara-cara komunikasi yang efektif menjadikan pustakawan sebagai sahabat bagi penggunanya. Walaupun kepribadian pustakawan tidak sama posisinya jika berada di perpustakaan yang dikelolanya. Untuk memahaminya dan mampu mengaktualisasi diri sendiri seorang pustakawan perlu dilakukan beberapa cara. Megingat pustakawan menjadi front liner pada

${ }^{11}$ Fatmawati, Endang. The Art Library: Ikatana Esai Bergizi tentang Seni Mengelola Perpustakaan 178 . 
bagian layanan yang langsung berhadapan dengan pengguna perpustakaan.

\section{Rumusan Masalah}

Berdasarkan latar belakang di atas maka dapat dirumuskan permasalahan sebagai berikut:

1. Apakah pengertian dari social skill?

2. Bagaimana penerapan social skill bagi pustakawan sekolah ?

3. Bagaimana hubungan social skill dengan minat baca?

\section{Pembahasan}

\section{Pengertian}

\section{a. Perpustakaan Sekolah}

Perpustakaan sekolah tumbuh dan berkembang seiring perubahan kebijakan pendidikan di Indonesia. Secara umum perpustakaan sekolah sangat dibutuhkan di lingkungan sekolah sebagai penunjang keberhasilan proses belajar mengajar. Tertuang dalam UU No. 20 Tahun 2003 disebutkan bahwa setiap satuan pendidikan formal dan nonformal menyediakan sarana dan prasarana yang memenuhi keperluan pendidikan sesuai dengan pertumbuhan dan perkembangan potensi fisik, kecerdasan intelektual, sosial, emosional, dan kejiwaan peserta didik. ${ }^{12}$

Perpustakaan sekolah dalam pengajaran dan pembelajaran untuk semua perpustakaan sekolah menyediakan informasi dan ide yang merupakan dasar keberhasilan fungsional dalam masyarakat masa kini yang berbasis pengetahuan dan informasi. Perpustakaan membekali murid berupa keterampilan pembelajaran sepanjang hayat serta imajinasi, memungkinkan mereka hidup sebagai warga negara yang bertanggung jawab. ${ }^{13}$

${ }^{12}$ Darmono, Perpustakaan Sekolah Pendekatan Aspek Manajemen dan Tata Kerja, (Jakarta: Grasindo, 2007). 1

${ }^{13}$ IFLA/UNESCO. School Libraries and Resources Centers Section. 2007. Manifesto Perpustakaan Sekolah IFLA/UNESCO. Perpustakaan Sekolah dalam Pengajaran dan Pembelajaran untu semua. Translated by Mr. Hernandono, Prof. Sulistyo Basuki dan Lucya Dhamayanti on behalf of the National Library of Indonesia. Tersedia di http://www.ifla org/VII/s11/Pubs/manisfesto-id. 
Disimpulkan bahwa salah satu yang menunjang manfesto dikeluarkan oleh IFLA membuktikan jika pustakawan sekolah dan guru bekerjasama, maka akan mencapai literasi, kemampuan membaca, belajar, memecahkan masalah memiliki keterampilan komunikasi yang lebih tinggi. ${ }^{14}$

A. Perpustakaan Sekolah sebagai Sumber Belajar

Perpustakaan sekolah memberikan kontribusi yang besar dalam kegiatan proses belajar mengajar disekolah. Adapun maksud dan tujuannya adalah untuk meningkatkan aktivitas siswa serta meningkatkan kualitas pendidikan dan pengajaran. Perpustakaan sekolah diperlukan keberadaannya dengan pertimbangan sebagai berikut: ${ }^{15}$

a. Perpustakaan sekolah merupakan sumber belajar di lingkungan sekolah,

b. Perpustakaan sekolah merupakan salah satu komponen sistem pengajaran,

c. Perpustakaan sekolah merupakan sumber penunjang kualitas pendidikan dan pengajaran

d. Perpustakaan sekolah sebagai laboratorium belajar yang memungkinkan peserta didik dapat mempertajam dan memperluas kemampuan untuk membaca, menulis, berpikir dan berkomunikasi.

Dengan demikian perpustakaan sekolah bertujuan menyerap dan menghimpun informasi, membantu meningkatkan daya pikir dan mendidik murid selaku pengguna agar dapat menggunakan bahan pustaka secara efisien. Seyogyanya perpustakaan sekolah dapat dijadikan sebagai tempat atau sarana fasilitas yang menumbuhkan semangat belajar, menumbuhkan gairah membaca dan mendorong siswa terus menggunakan perpustakaan sebagai tempat yang paling senang untuk di kunjungi.

Di beberapa tempat diperpustakaan sekolah sampai dengan perpustakaan perguruan tinggi banyak keluhan yang kurang baik dari pemustaka salah satunya pelayanan pustakawan itu sendiri yang memiliki

htm.Download 5 Januari 2018.

${ }^{14}$ Darmono, Perpustakaan Sekolah Pendekatan Aspek Manajemen dan Tata Kerja,20.

${ }^{15}$ Yoseph Mbulu, Pemanfaatan Perpustakaan Sekolah Dalam Kegiatan Belajar-Mengajar. Majalah Pendidikan. XIX, 89. 
kesan kurang humanis. ${ }^{16}$ Seorang pengguna/pemustaka mengatakan bahwa pustakawan menyenangkan, petugasnya ramah dalam melayani, akan mempengaruhi pengguna/pemustaka lain untuk mengunjungi perpustakaan.

Lain halnya apabila seorang pengguna/pemustaka mengatakan bahwa pustakawan di perpustakaan tidak simpatik, galak, tidak ramah kurang tanggap terhadap pengguna/pemustaka yang kesulitan mencari. Padahal itu baru sumber daya manusia, belum sarana dan prasarana yang harus tersedia di perpustakaan.

\section{b. Pustakawan sebagai Pelayan Jasa}

Sesuai dengan kompetensi dan kualifikasi akademik yang dimiliki, seorang pustakawan memiliki tugas melakukan pengembangan koleksi dan memberikan pelayanan yang dibutuhkan oleh pengguna serta memberdayakan informasi secara optimal agar dapat disebarkan kepada pengguna.

Seiring berkembangnya zaman, pustakawan senantiasa dituntut berperan penting dalam mengikuti arus perubahan. Perubahan yang dirasakan sangat berkembang dengan pesat yaitu arus informasi dalam proses pengolahan perpustakaan. Peran seorang pustakawan bukan hanya sebagai penjaga koleksi bahan pustaka dan tumpukan-tumpukan buku didalam rak kayu. Serta melakukan kegiatan sirkulasi sebagaimana tugas rutin seperti biasanya. Ditambah lagi dengan seabrek rutinitas pekerjaan lainnya. Sehingga membuat pustakawan merasa jenuh dan bosan terhadap pekerjaan yang dilakukannya.

Saatnya pustakawan bergerak naik menjadi pengelola informasi atau manajer informasi profesional berbasis teknologi informasi. Melengkapi kebutuhan pengguna terutama siswa dengan segala fasilitas teknologi mampu menyediakan segala bentuk informasi yang tersebar luas dan dapat digunakan oleh siswa selaku pemustaka di sekolah. Di samping itu, pustakawan juga

16 Maslahah, Khoirul. Bunga Rampai Layanan Perpustakaan Berbasis Humanisme.(Surakarta: Bunga Rampai), 2013. 
turut berperan sebagai pembimbing, fasilitator dan information specialist, bahkan bisa juga berperan sebagai evaluator.

Perubahan yang terjadi tidak lantas membuat pustakawan meninggalkan rutinitas pekerjaan sebelumnya. Karena pustakawan juga dituntut untuk tetap melayani pemustaka secara profesional dan berpartisipasi dalam mencapai tujuan pendidikan. Pustakawan tidak hanya dituntut untuk dapat menunjukkan eksistensi dan peranya, melainkan pustakawan hendaknya selalu berupaya memberikan layanan terbaik kepada pemustaka.

Agar layanan terbaik tersebut terwujud di perpustakaan maka seorang pustakawan hendaknya memiliki kompetensi dibidang ilmu pengetahuan baik tentang ilmu perpustakaan khususnya, keterampilan sosial baik internal maupun eksternal dengan tujuan memberikan layanan prima sebagai wujud citra diri pustakawan profesional.

Citra perpustakaan yang hanya sebagai gudang buku dengan penataan koleksi asal-asalan dan tidak sesuai aturan di perpustakaan harus segera diubah menjadi tempat belajar yang menyenangkan. Untuk memperbaiki infrastruktur sebuah perpustakaan tidak mahal, hanya dengan menunjukkan sebuah kreativitas dari pustakawan dan melibatkan seluruh pemustaka yaitu siswa serta didukung oleh seluruh warga sekolah maka perpustakaan sekolah mengalami sebuah perubahan dalam mewujudkan literasi di sekolah. Lebih dari pada itu, pustakawan sekolah harus seorang yang memiliki idealisme bukan hanya seorang petugas yang datang disaat jam kerja serta memenuhi kewajiban dengan mengharapkan gaji semata.

Karena semua bentuk pelayanan yang diberikan perpustakaan kepada penggunanya tertentu bersifat jasa sosial. ${ }^{17} \mathrm{Hal}$ ini mengandung arti bahwa segala jenis pelayanan jasa yang dilakukan perpustakaan tidak hanya bertujuan untuk mencari keuntungan material (komersial). ${ }^{18}$

${ }^{17}$ Pawit M Yusuf, Ilmu Informasi, Komunikas Dan Kepustakaan. (Jakarta: Bumi Aksara: 2009), 394.

${ }^{18}$ Ibid. 398 


\section{c. Keterampilan Bagi Pustakawan Sekolah}

Agar dapat memberikan layanan yang baik dan prima sesuai dengan fungsinya, perpustakaan memerlukan tenaga pengelola perpustakaan atau yang biasa disebut dengan pustakawan. Pustakawan dengan latar belakang ilmu perpustakaan, seharusnya lebih menguasai bidang ilmu tentang perpustakaan. Terutama dalam hal pelayanan pengguna.

Namun hal tersebut tidak bisa juga dibuktikan bahwa seorang dengan ilmu perpustakaan mampu mengimplementasikan ilmu yang dimilikinya. Perlunya social skill di perpustakaan bukan hanya diutamakan kepada pustakawan non perpustakaan. Tetapi pustakawan yang berstandar dan sesuai ilmu perpustakaan perlu menerapkan social skill ini.

Social Skill atau keterampilan pustakawan akan sangat berpengaruh dalam meningkatkan minat baca yang ada di perpustakaan. Pustakawan dituntut untuk lebih aktif dalam memenuhi kebutuhan pengguna, berkomunikasi dengan baik, dan mampu menguasai perkembangan teknologi informasi. Seorang pustakawan tidak lagi gaptek dengan namanya teknologi. Dengan demikian, maka yang menjadi prioritas utama dari kompetensi yang dimiliki pustakawan mampu memberikan layanan terbaik (prima) kepada siswa selaku pemustaka. ${ }^{19}$

Pustakawan adalah seorang yang memiliki komptensi yang diperoleh baik dari pendidikan dan atau pelatihan tentang kepustakawanan. Perpustakaan yang ramai dikunjungi oleh siswa, berarti menunjukkan bahwa kompetensi pustakawannya sangat baik. Citra seorang pustakawan akan terlihat karena kinerja dan totalitasnya dalam melayani kebutuhan pengguna perpustakaan.

Kompetensi adalah total dari kemampuan dan daya dukung yang secara real dimiliki oleh setiap orang. Pemustaka hanya akan melihat seberapa besar kontribusi dan partisipasi seorang pustakawan dalam memberikan informasi yang mereka butuhkan. Mewujudkan citra seorang pustakawan profesional dilihat dari kompetensi keahlian yang dimiliki yaitu: Hard Skil

${ }^{19}$ Maslahah, Khoirul. Bunga Rampai Layanan Perpustakaan berbasis Humanisme. (Surakarta: BungaRampai), 2013. 
dan Soft Skill. Kedua kompetensi diatas saling berkesinambungan dalam meningkatkan kapasitas dan kinerja seorang pustakawan. Dengan melakukan kedua cara tersebut, maka pustakawan mendapatkan tempat dihati para penggunanya.

Soft Skill berperan dalam dua pertiga dari serangkaian kompetensi yang dibutuhkan untuk mencapai kesuksesan, dimana satu pertiganya lagi adalah hard skill. Soft Skill merupakan aktualiasi kecerdasan emosi, yang pada dasarnya terbangun ke dalam dua bagian kompetensi intra pribadi dan interpribadi. Hard Skill merupakan kompetensi interpersonal yaitu kemampuan memahami dan mengendalikan diri sendiri. Kompetensi ini terdiri dari pemahaman sukses, evaluasi diri, citra diri, goal setting, motivasi diri. Kompetensi interpersonal yaitu kompetensi kita untuk bergaul dan berinteraksi dengan orang lain.

Soft Skill lebih mengutamakan kemampuan intrapersonal dan interpersonal. Secara garis besar soft skill bisa digolongkan kedalam dua kategori yaitu intrapersonal dan interpersonal skill. Intrapersonal Skill meliputi: (1) Self Awareness (Improvement, self control, trust, worthiness, time/ source management, proactivity, conscience. Sedangkan interpersonal skill meliputi: Social awarenes (political awareness, developing others, leveraging diversity, service oriention, empathy dan social skill, leadership, influence, communication, conflict management, coperation, team work, synergy). Kemampuan soft skill antara lain meliputi kepribadian, keterampilan berkomunikasi, kepemimpinan, keterampilan beroganisasi dan kerja kelompok/tim. ${ }^{20}$

Soft Skill untuk meningkatkan profesionalisme pustakawan meliputi:(a) Listening Skill yaitu kemampuan mendengarkan pendapat, masukan-masukan dan ide-ide dari pemustaka. Kemampuan ini membutuhkan tingkat kesabaran tinggi karena ada kalanya pemustaka bertindak "kurang ramah" (terlalu rewel, minta dilayani serba cepat atau semacamnya). (b) communication skills, yaitu kemampuan berkomunikasi

${ }^{20}$ Fatmawati, Endang. The Art Library: Ikatana Esai Bergizi tentang Seni Mengelola Perpustakaan. 168 
yang memadai, efektif dan menyenangkan untuk membina hubungan baik dengan orang lain khususnya pemustaka, melalui komunikasi verbal maupun non verbal. (c) public relation skill, kemampuan membangun relasi dan kerjasama dengan pemustaka, dengan pustakawan ataupun dengan perpustakaan dan orgnaisasi-organisasi lainnya untuk meningkatkan kualitas diri dan pekerjaannya. ${ }^{21}$

Jika pustakawan menguasai Soft Skill dengan baik setidaknya akan mengalir manfaat yang dapat dirasakan, diantaranya sebagai berikut ${ }^{22}$ :

Pertama, soft skill dapat memotivasi diri dan orang lain yang artinya dapat memberikan pengaruh positif dalam menyikapi masalah-masalah kehidupan terutama yang berkaitan dengan masalah pekerjaan.

Kedua, soft skill mampu membentuk pribadi yang bertanggung jawab, artinya lingkungan kerja seseorang pustakawan membutuhkan pribadi yang memiliki tanggung jawab, mengingat dunia kepustakawanan memiliki keunikan kerja yang tidak semua orang dapat menjalaninya, kecuali mereka yang sudah memiliki kemampuan, pengetahuan, wawasan, dan pengalaman di bidang perpustakaan.

Ketiga, soft skill pustakawan akan mampu membangun relasi, berkomunikasi, negosisasi, beradaptasi dengan lingkungan. Karena lingkungan pemustaka beraneka ragam sehingga membutuhkan individu yang mampu menyamakan persepsi, membangun ide bersama dan menumbuhkan gairah untuk selalu berkembang dan menjadi pribadi yang tangguh.

Keempat, dengan menguasai soft skill yang baik, maka pustakawan mampu berkreasi, berinovasi dan beriwirausaha, memimpin, membangun kerjasama dan juga mengelola sumber daya dan lain sebagainya.

Konsep Hard Skill dan Soft Skill seorang pustakawan bila digambarkan dalam bentuk tabel berikut ini ${ }^{23}$ :

${ }^{21}$ Suwarno, Wiji. Library life style: Trend dan Ide Kepustakawanan. (Yogyakarata: Ladang kata , 2016) 252-259.

${ }^{22}$ Suwarno, Wiji. Library life style: Trend dan Ide Kepustakawanan.

${ }^{23}$ Rotminato, Mohamad. Konsep Hard Skill, Soft Skill Dan Spiritual Skill Pustakawan Dalam 
Soft Skill Pustakawan

Hard Skill Pustakawan

1. Sabar dalam mendengarkan dan me- 1. Menguasai teori pencarian informasi nyimak (Listening Skill) dan metode penyelesaian masalah

2. Ramah, hangat dan menyenangkan dalam berkomunikasi dan bertutur kata (Communication Skill).

2. Menguasai teknologi, teori komunikasi dan bahasa Inggris.

3. Menguasai TIK (Mesin Pencari jejaring sosial, email, OPAC, Website, perpustakaan dan lain-lain).

ide, pendapat secara tertulis dengan santun dan menggunakan gaya bahasa yang baik.

4. Menguasai teori dan ilmu-ilmu perpustakaan pada umumnya.

4. Dapat bekerjasama dengan siapa saja (Public Relation Skill)

Lebih jelasnya lagi, berikut beberapa contoh elemen Soft Skill yang bisa diterapkan oleh seorang pustakawan sebagai berikut: ${ }^{24}$

1) Memiliki kecerdasan emosional (Emotional Quotient.

2) Mempunyai integritas personal/kejujuran.

3) Memiliki rasa solidaritas.

4) Mampu merasakan seperti apa yang dirasakan orang lain (Emphaty).

5) Kemampuan membangun kepercayaan diri (self confidence).

6) Kemampuan manajerial/kemahiran kepimpinan (leadership).

7) Kecakapan beradaptasi

8) Disiplin

9) Memiliki kemampuan mendengarkan

10) Bertanggung jawab (responsibility).

11) Kemampuan public speaking

12) Kemampuan bekomunikasi lisan maupun tertulis.

13) Kemampuan berkomunikasi verbal dan nonverbal.

14) Kemampuan menulis.

15) Kemampuan mengutarakan ide atau gagasan

Mengahadapi Era Library 3.0, dalam jurnal Pustakaloka, Vol.7 No. 1 Tahun 2015.

${ }^{24}$ Fatmawati, Endang. The Art Library: Ikatan Esai Bergizi tentang Seni Mengelola Perpustakaan.(Semarang: Badan Penerbit Diponegoro, 2010).169 
16) Kemampuan menyelesaikan / memecahkan masalah (conflict resolution/ problem solving).

17) Kemampuan presentasi

18) Memiliki etos kerja dan motivasi yang tinggi.

19) Kemampuan membaca cepat (speed reading)

20) Kemampuan mempengaruhi orang lain.

21) Kemampuan mengolah informasi.

22) Memiliki komitmen dan ketertarikan terhadap pekerjaan.

23) Kamuan untuk terus belajar yang kuat guna mencapai keunggulan

24) Mempunyai visi kedepan dengan semangat untuk maju dan tidak takut dengan hal-hal yang baru.

25) Kemampuan bekerjasama didalam suatu team (team work) dan berkolaborasi.

26) Kemampuan berpikir, berwawasan dan bertindak positif (positive thingking).

27) Berwawasan/ berjiwa kewirausahaan (entrepreneurship).

28) Kemampuan intelegensi/pengembangan keratifitas.

29) Memiliki motivasi kerja yang tinggi.

30) Kemampuan mengambil dan membuat keputusan (decision making).

31) Kemampuan berogranisasi.

32) Kemampuan bernegosisasi.

33) Sikap sopan dan santun dalam berprilaku.

34) Relasi/hubungan antar pribadi (interpersonal relationship/human relation skills).

35) Berkepribadian.

36) Memiliki Sikap prilaku dewasa.

37)Kemampuan mempromosikan,"membujuk" dan memperkenalkan perpustakaan.

Berdasarkan keterangan diatas, bahwa sebagai pustakawan jika ingin menjadi contoh dan mendapatkan citra yang baik maka selama melakukan 
pekerjaan dalam bidang layanan yang lebih baik. Terus berupaya melakukan sebuah perubahan, karena pustakawan merupakan agen perubahan informasi.

Perilaku pustakawan yang baik merupakan cerminan diri dan menjadi penilaian tersendiri bagi para penggunanya. Model pustakawan ideal menjadi branded bagi para pustakawan untuk bisa mendapatkan penghormatan dan penghargaan kepada khalayak publik. ${ }^{25}$

\section{d. Peran Perpustakaan, Pustakawan Penggerak Minat Baca}

Perpustakaan bisa menjadi sarana untuk menumbuhkan dan meningkatkan minat baca bila perpustakaan dapat berfungsi sebagai wadah pendidikan dalam mengembangkan minat baca. Kegemaran membaca bersumber pada perpustakaan sekolah. Sampai saat ini belum terlihat gambaran yang sesuai bagi perpustakaan sebagai pusat edukasi pengembangan minat baca. Sebagai contoh perpustakaan yang nyaman dan tenang serta mencirikan suatu tempat yang paling senang untuk dikunjungi oleh para penggunanya. Perpustakaan yang ada, belum sepenuhnya memenuhi harapan sebagai tempat atau sarana untuk menggairahkan semangat belajar, minat baca, dan mendorong siswa membiasakan belajar secara mandiri. ${ }^{26}$

Perpustakaan berperan penting dalam membina dan menumbuhkan minat baca. Membaca tidak bisa di lepaskan dari keberadaan dan tersedianya koleksi pada suatu tempat yaitu perpustakaan. Menumbuhkan dan mengembangkan minat baca, perilaku maupun kebebasan membaca merupakan suatu upaya yang tidak mudah dan tidak dapat pula dilakukan dengan proses yang cepat. Untuk membangun kebiasaan gemar membaca, perlu dimunculkan minat atau ketertarikan seseorang untuk mengenal bacaan kemudian melakukan aktivitas membaca.

Disekolah-sekolah tertentu yang sudah maju menganggap pentingnya perpustakaan sekolah dan pustakawan sebagai motivasi dan penggerak dalam

${ }^{25}$ Personal Branding,

${ }^{26}$ Supriyanto dkk, Aksentuasi Perpustakaan Dan Pustakawan, (Jakarta: Ikatan Pustakawan Indonesia Pengurus DKI, 2006 ), 276. 
mewujudkan kebiasaan membaca siswa. Berbicara mengenai minat baca, banyak sekali teori dari para ahli dalam mendefenisiskan tentang minat baca.

Minat baca adalah minat sesorang terhadap sesuatu kecendrungan hati yang tinggi, gairah atau keinginan seseorang terhadap sesuatu. Minat yang dikembangkan pada usia dini selanjutnya dapat dijadikan landasan bagi berkembangnya budaya baca, subur dan terpuruknya perkembangan budaya baca tentu sangat terganung pada ketersediaannya bahan bacaan yang memadai. ${ }^{27}$

Minat adalah keinginan atau kecendrungan hati yang tinggi terhadap sesuatu. ${ }^{28}$ Dalam kamus Bahasa Indonesia, minat berarti perhatian, kesukaan, kecendrungan hari. ${ }^{29}$ Menumbuhkan minat baca adalah sebuah proses yang memerlukan waktu yang panjang. Banyak faktor yang terlibat, salah satunya pembiasaan yang harus dimulai sejak dini. Minat ditandai dengan rasa suka dan terkait pada suatu hal atau aktivitas tanpa ada yang menyuruh.

Dalam Kamus Besar Bahasa Indonesia kata minat memiliki arti kecendrungan hati yang tinggi terhadap sesuatu, gairah dan keinginan. Artinya, harus ada kerelaan dari seseorang untuk melakukan sesuatu yang disukai dan tanpa paksaan. Semakin kuat atau semakin besar hubungan tersebut maka semakin dekat minat seseorang. ${ }^{30}$

Pengertian diatas menunjukkan bahwa minat merupakan suatu kecendrungan yang membuat seseorang untuk berusaha, mencari atau mencoba aktivitas-aktivitas dalam bidang tertentu. Minat berkaitan erat dengan aspek kognitif dan afektif. aspek kognitif berupa konsep positif suatu objek dan berpusat pada manfaat objek tersebut. Sedangkan Aspek afektif akan nampak rasa senang atau tidak senang dan keputusan terhadap objek tersebut.

${ }^{27}$ Sutarno NS, Tanggung Jawab Perpustakaan Dalam mengembangkan Masyarakat Informasi, (Jakarta: Panda Rei, 2005), 20.

${ }^{28}$ Tim Pengkajian dan Pengembangan Minat Baca, Pedoman Peningkatan Minat Baca (Jakarta: Perpusnas RI, 2005) 7.

${ }^{29}$ Rony Gunawan K, Kamus Lengkap Bahasa Indonesia, (Surabaya: Tertib Terang, 2001) 298

${ }^{30}$ Ibid. 744 
Peran yang dilakukan perpustakaan dalam menciptakan tumbuhnya kondisi membaca di lingkungan sekolah adalah sebagai berikut: ${ }^{31}$

a. Memilih bacaan yang menarik bagi pengguna perpustakaan

b. Mengajukan berbagai cara penyajian pelajaran di sekolah dikaitkan dengan tugas-tugas di perpustakaan

c. Memberikan berbagai kemudahan dalam mendapatkan bacaan yang menarik untuk pengunaan perpustakaan.

d. Memberikan penghargaan kepada siswa yang paling banyak meminjam buku

e. Meningkatkan bula Mei setiap tahun sebagai bulan buku Nasional

f. Melakukan berbagai kegiatan seperti lomba minat baca dan kegemaran membaca untuk anak sekolah

g. Menanamkan kesadaran dalam diri pemakai perpustakaan bahwa membaca sangat penting dalam kehidupan, terutama dalam mencapai keberhasilan sekolah.

h. Perpustakaan perlu melakukan berbagai macam promosi kepada masyarakat berkaitan dengan peningkatan minta dan kegemaran membaca.

i. Perpustakaan perlu dikelola dengan baik agar pemakai merasa betah berkunjung ke perpustakaan

j. Memberikan kebebasan secara leluasa kepada pemakai perpustakaan. Hal ini dimaksudkan untuk memotivasi anak, mencari dan menemukan bacaan yang sesuai dengan minatnya.

Membangun budaya baca, bukan hanya sekedar menjadi tugas pustakawan dalam menyediakan koleksi atau ruang bacaan. Melainkan pustakawan dituntut dan terlibat aktif memberikan ide, perilaku dan budaya yang baik dari generasi yang tidak suka membaca menjadi generasi suka membaca. Dari generasi asing yang tidak suka dengan buku menjadi generasi pencinta buku.

${ }^{31}$ Darmono, Perpustakaan Sekolah Dan Pendekatan Aspek Manajemen Dan Tata Kerja, (Jakarta: PT.Gramedia Widiaswara Indonesia, 2007), 221. 
Minat adalah perpaduan kegiatan dan kemauan yang dapat berkembang jika ada motivasi. ${ }^{32}$ Minat merupakan salah satu dimensi dari aspek afektif yang dapat berperan juga dalam kehidupan belajar seorang siswa. Dalam Kamus Besar Bahasa Indonesia secara umum menjelaskan bahwa arti minat adalah kecendungan hati yang tinggi terhadap sesuatu, gairah, keinginan. ${ }^{33}$ Dalam hal ini dikaitakn dengan membaca sebagai salah satu bentuk kegiatan yang membutuhkan suatu keingan dari masing-masing orang. Dengan demikian rasa keinginan tersebut bisa mempengaruhi minat sesorang dalam membaca.

Minat baca ialah sesuatu yang menarik perhatian untuk dibaca, tetapi kalau tidak menarik tidak akan dibcaa, oleh sebab itu membaca bukan merupakan faktr turunan tetapi merupakan suatu proses yang harus dilatih secara terus menerus. Apabila tlah menjadi kebiasaan dan setelah menjadi suatu kebutuhan maka minat baca berubah menjadi sebuah kebudayaan membaca. (budaya baca). ${ }^{34}$

Minat membaca merupakan suatu keinginan yang timbul dari dalam diri seseorang untuk membca. Terdapat dua proses timbulnya minat seseorang, yaitu:

1. Minat yang timbul dengan sendirinya (alami). Minat ini merupakan pembawaan sejak lahir.

2. Minat yang perlu ditumbuhkan atau ditimbulkan. Biasanya mulai dilakukan pada kategori-anak-anak saat menginjak dunia pendidikan, membaca menjadi suatu yang langka dilakukan oleh oleh anak-anak. Walaupun keingina membaca biasa dilakukan pada jenis koleksi seperti komik.

Dalam hal ini minat membaca adalah kebiasaan yang diperoleh seseorang dilahirkan bukan kebiasaan bawaan. Maka dari itu minat membaca terdiri dari beberapa indikator, yaitu:

${ }^{32}$ Tampubolon, Mengembangkan Minta Dan Kebiasaan Membaca Pada Anak, Bandung: Angkasa, 1993. 41

${ }^{33}$ Kamus Besar Bahasa Indonesia.

${ }^{34}$ Natadjumena, Rachmad. Masyarakat Dan Minat Baca”. Dalam media pustakawan, Vol.12. No,2 Juni 2005. 3 
1. Menyediakan waktu luang untuk membaca.

Ciri orang yang mempunyai minat baca yang tinggi adalah selalu memanfaatkan waktu luang untuk membaca, suka mencari waktu dan kesempatakan membaca, senantiasa berkeinginan membaca (semua jenis bacaan), memanfaatkan membaca sesuai dengan kebutuhan, dan melakukan kegiatan membaca dengan senang hati. ${ }^{35}$

2. Memiliki kebiasan membaca

Seseorang dianggap memiliki kebiasaan membaca salah satu cara dengan menyediakan waktu untuk membaca. Serta membaca dalam segala kesempatan yang dilakukan dikehidupan sehari-hari. ${ }^{36}$

3. Ketertarikan terhadap bahan bacaan

Rasa keingintahuan atau perhatian (attention) terhadap suatu objek dapat menimbulkan rasa ketertarikan atau menaruh minat pada sesuatu (interes). ${ }^{37}$

Dari semua pengertian tentang minat membaca, dapat ditarika sebuah kesimpulan bahwa membaca menjadi sebuah kebiasaan asalkan didapat dengan adanya dorongan baik dari diri sendiri maupun orang lain. Dalam lingkungan keluarga, faktor pendorong minat mebca adalah dari keluarga itu sendiri, namun dalam dunia pendidikan yang menjadi faktor pendorong minat baca adalah guru dan penyediaan perpustakaan sebagai sarana penyedia informasi bacaan bagi peserta didiknya.

Penyedia sarana prasarana yang mendukung pada sebuah perpustakaan dapat dibagi menjadi empat bagian, yaitu: ${ }^{38}$

1. Gedung atau tata ruang perpustakaan.

2. Koleksi yang memadai

${ }^{35}$ Suyono, 2001 halaman 20.

${ }^{36}$ Sudarsono, Undang dan Baskoro, Pembinaan Minat Baca, Jakarta: 2007.

${ }^{37}$ Prasetyono, Djoko Andi (n.d). “Cerminan Etika Dalam Hubungan Antar-Manusia: Analisa pada Beberapa Ornamen Candi Sukuh”. Dalam http //journal.unair.ac.id/filepdf/Cerminan\%etika. pdf.Diakses 04 Januari 2018.

${ }^{38}$ Soeatminah, Perpustakaan Kepustakawanan dan Pustakawan. Yogyakarta: Kanisius, 2002, 18. 


\section{Perabot perlengkapan}

4. Pustakawan.

Berdasarkan keempat sarana dan prasarana pendukung minat membaca di perpustakaan salah satu faktor utamanya adalah pustakawan, dalam hal ini pastinya setiap sekolah sudah memiliki ruang atau gedung perpustakaan yang memadai sesuai standar pendidikan. Namun sosok pustakawan belum tentu tersedia di setiap jenjang perpustakaan terutama disekolah.

Dari sinilah, pustakawan menjadi salah satu penggerak dari berjalannya program-program kegiatan di perpustakaan terutama berkaitan dengan minat baca. Keberhasilan perpustakaan sebagai lembaga yang bergerak dalam bidang jasa sangat tergantung dari sistem dan pelaksanaan aspek layanan yang diberikan kepada pemakainya. Koleksi yang dimiliki oleh perpustakaan merupakan aset kekayaan yang harus dimanfaatkan sebesar-besarnya oleh pengguna perpustakaan terutama siswa sebagai peserta didik di sekolah. Sehingga dengan perannya yang startegis, perpustakaan perlu didukung dengan kemampuan teknik yang efisien dan efektif dalam penggunaan sarana layanan di perpustakaan.

Secara umum membaca mempunyai tujuan untuk mendapatkan informasi baru. Dalam kenyataannya terdapat tujuan yang lebih khusus dari kegiatan membaca, yaitu:

1. Membaca untuk tujuan kesenangan. Termasuk dalam kategori ini adalah membaca novel, surat kabar, majalah dan komik. Menurut David Eskey tujuan membaca semacam ini adalah Reading for Pleasure. Bacaan yang dijadikan obyek kesenangan menurut David adalah "bacaan ringan”

2. Membaca untuk meningkatkan pengetahuan seperti pada membaca buku-buku pelajaran dan buku-buku ilmu pengetahuan. Kegiatan membaca untuk meningkatkan pengetahuan yang disebut dengan Reading For Intelectual Profit.

3. Membaca melakukan suatu pekerjaan, misalnya mekanik perlu membaca buku petunjuk, ibu-ibu membaca booklet tentang resep masakan, 
membaca prosedur kerja dari pekerjaan tertentu. Kegiatan membaca semacam ini dinamakan reading for work.

Perpustakaan memilki peranan yang signifikan untuk mendukung gemar membaca dan meningkatkan literasi informasi juga untuk mendukung siswa dapat belajar secara independen. Salah satu hasil penelitian literasi di tingkat Internasional menyimpulkan dalam sebuah kalimat: menemukan cara siswa untuk mengajak siswa membaca merupakan suatu jalan yang sangat efektif untuk perubahan sosial. ${ }^{39}$

\section{Kesimpulan}

Menghadapi sebuah perubahan perkembangan ilmu pengetahuan, teknologi dan informasi menjadi tuntuntan sekaligus tantangan bagi seluruh lapisan masyarakat. Pustakawan merupakan jembatan dalam memberikan informasi secara luas membutuhkan social skill sebagai citra diri seorang pustakawan profesional yang mampu bekerja pada bidangnya. Jika dalam diri seorang pustakawan memilki pengetahuan akan keduanya (soft skill dan hard skill) mampu mengimplementasikannya, maka akan tumbuh jiwa yang mencintai pekerjaannya serta selalu ikhlas dalam melaksanakan tugasnya. Tidak memandang sebuah harga atas jerih payah, namun semata niat beribadah karena Allah swt.

Dengan demikian diharapkan seorang pustakawan mampu bersaing di dunia luar serta dapat meningkatkan profesinya sebagai seorang pustakawan.Menjalani profesi yang sudah diraihnya, dengan niat dan tujuan mencerdaskan anak bangsa sesuai yang tertuang dalan UUD 1945, paragraph ketiga "turut serta mencerdaskan kehidupan bangsa ..." ini merupakan kewajiban bangsa Indonesia terutama Pustakawan sebagai penggerak literasi informasi terutama dalam dunia pendidikan, yaitu perpustakaan sekolah.

${ }^{39}$ Suherman, Perpustakaan sebagai jantung sekolah referensi pengelolaan perpustakaan 


\section{Daftar Pustaka}

Aziz, Safrudin. Menjadi Pustakawan Progresif. Yogyakarta: Ideas Press Yogyakarta, 2012.

Darmono, Perpustakaan Sekolah Dan Pendekatan Aspek Manajemen Dan Tata Kerja, (Jakarta: PT.Gramedia Widiaswara Indonesia, 2007).

------. Manajemen dan Tata Kerja Perpustakaan Sekolah. (Jakarta: Grasindo 2001).

Fatmawati, Endang. The Art Library: Ikatan Esai Bergizi tentang Seni Mengelola Perpustakaan. (Semarang: Badan Penerbit Diponegoro, 2010).

Hartono. Manajemen Perpustakaan Sekolah: Menuju Perpustakaan Modern dan Profesional.(Yogyakarta: Ar-Ruz Media, 2016).

Kamus Besar Bahasa Indonesia.

Maslahah, Khoirul. Bunga Rampai Layanan Perpustakaan berbasis Humanisme.(Surakarta: Bunga Rampai), 2013.

Natadjumena, Rachmad. Masyarakat Dan Minat Baca". Dalam media pustakawan, Vol.12.No,2 Juni 2005. 3

Pawit M Yusuf, Ilmu Informasi, Komunikas Dan Kepustakaan. (Jakarta: Bumi Aksara: 2009), 394.

Qalyubi, Syihabuddin. Dasar-Dasar Ilmu Perpustakaan Dan Informasi. Yogyakarta: Jurusan Ilmu Perpustakaan dan Informasi Fakultas Adab, 2003.

Rony Gunawan K, Kamus Lengkap Bahasa Indonesia, (Surabaya: Tertib Terang, 2001) 298

Rotminato, Mohamad. Konsep Hard Skill, Soft Skill Dan Spiritual Skill Pustakawan Dalam Mengahadapi Era Library 3.0, dalam jurnal Pustakaloka, Vol.7 No. 1 Tahun 2015.

Soeatminah, Perpustakaan Kepustakawanan dan Pustakawan. Yogyakarta: Kanisius, 2002, 18.

Sudarsono, Undang dan Baskoro, Pembinaan Minat Baca, Jakarta: 2007. 
Suherman, Perpustakaan Sebagai Jantung Sekolah Referensi Pengelolaan Perpustakaan Sekolah (Bandung: MQS Publishing, 2009).

Supriyanto dkk, Aksentuasi Perpustakaan Dan Pustakawan, (Jakarta: Ikatan Pustakawan Indonesia Pengurus DKI, 2006 ), 276.

Sutarno NS, Tanggung Jawab Perpustakaan Dalam mengembangkan Masyarakat Informasi, (Jakarta: Panda Rei, 2005), 20.

Suwarno, Wiji. Library Life Style: Trend dan ide kepustakawanan. Yogyakarta: Ladang Kata, 2016.

Tampubolon, Mengembangkan Minta Dan Kebiasaan Membaca Pada Anak, Bandung: Angkasa, 1993.

Tim Pengkajian dan Pengembangan Minat Baca, Pedoman Peningkatan Minat Baca (Jakarta: Perpusnas RI, 2005) 7.

Undang-undang R.I. No.2 Tahun 1989 tentang Sistem Pendidikan Nasional. Jakarta: Armas Duta Jaya, 189.

Yoseph Mbulu, Pemanfaatan Perpustakaan Sekolah Dalam Kegiatan BelajarMengajar. Majalah Pendidikan. XIX, 89.

\section{Jurnal}

Http://Lib.Untidar.Ac.Id/Wp-Content/Uploads/2017/01/Soft-Skill-DanSpiritual-Skill.Pdf. Tanggal Download 14 Oktober 2017. Pukul 17.00 wib.

IFLA/UNESCO. School Libraries and Resources Centers Section. 2007. Manifesto Perpustakaan Sekolah IFLA/UNESCO. Perpustakaan Sekolah dalam Pengajaran dan Pembelajaran untu semua. Translated by Mr. Hernandono, Prof. Sulistyo Basuki dan Lucya Dhamayanti on behalf of the National Library of Indonesia. Tersedia di http://www. ifla org/VII/s11/Pubs/manisfesto-id.htm.Download 5 Januari 2018.

Prasetyono, Djoko Andi (n.d). “ Cerminan Etika Dalam Hubungan AntarManusia: Analisa pada Beberapa Ornamen Candi Sukuh”. Dalam http //journal.unair.ac.id/filepdf/Cerminan\%etika.pdf.Diakses 04 Januari 2018. 